\title{
Comparison between PID and Artificial Neural Networks to Control of Boiler for Steam Power Plant
}

Salim H., Sultan Kh. F., Jawad R.

University of Technology, Al-Sinaa St., 10066 Baghdad, Iraq

\author{
Article info: \\ Paper received: \\ The final version of the paper received: \\ Paper accepted online:
}

October 12,2018

January 2, 2019

January 7, 2019
*Corresponding Author's Address: rjawad192@gmail.com

\begin{abstract}
This paper presents is to develop and compare neural network and conventional based controllers for a boiler of steam power plant. Designs of two different controllers for pressure and temperature are presented for keeping the boiler working in normal condition and improve efficiency. These controllers consist of NARMA controller of ANN and a conventional proportional-integrator-derivative (PID) controller. These parameters are adjusted by built a model and implementation in MATLAB program according to the requisite of the steam power plant and the control objectives. The results show a neural network is best controlled and superior performances of power plant from PID controller artificial neural network and PID have been applied in Al-Dura power plant in Baghdad. Therefore, neural networks have been extensively utilized in many industrial applications.
\end{abstract}

Keywords: Artificial Neural Network, control, PID, NARMA controller.

\section{Introduction}

The control system is an important part of steam power plant. When a control system is weakening lead to damage and shutdown of boiler for this reason design modeling of control systems and applied of different types of controllers of industrial plants. Applications of steam generation modeling to control systems can classify into ANN and PID. Many authors have suggested system controller and models by using intelligent technique such as applied Artificial neural network (ANN) to obtain the relationships between input and output data variables of the system. The neural network controllers are extensively used for their suppleness for completion on many systems and good reference track capacity [1]. The authors applied dynamic artificial neural network base on genetic algorithm (GA) to control and identify the advantages and disadvantages of ANN trained by GA. a genetic algorithm utilzed to train a Layer-Recurrent Network, Focused Time-Delay Neural Network, a Elman Network, and Nonlinear Autoregressive Network with exogenous inputs. The results of simulation provide a good accuracy of model the generalization by a nonlinear system of neural network. The training time is shorter of dynamic neural networks and faster of convergence speed. Also the generalization of the Elman network and the NARX network are better than the FTDNN and the LRN networks and the training error of the LRN network is the smallest among the DNNs. The NARX and the Elman network may be describe the complex system because of the back-forward in the DNN. Arrange of the system will be set before the training because the FTDNN network is the feed-forward multilayer [2]. This study obtained application of neural network for control of solar plants. This plant consists of a hybrid diagram combining the possibilities of neural networks for estimate purposes with the well-know hypothesis and general industrial application of PID techniques. The neural network is training base on data that measured from the plant provided that a way of development between a set of PID controllers and verify the use of several local linear controllers to cope with changes in the plant behavior induce by different operating conditions. Experimental results show the neural networks are able to learn by data systems this data collected at "Platforma Solar de Almeria" (Spain), neural network is see as an extension rather than substitute of linear identifiers and controllers that can be previously working and applied to a plant model and the computational requirements with a small initial knowledge .the results were obtained from this control strategy [3]. In this study present use of Artificial Intelligent and PI Controller to analysis dynamic performance and control methodology developed by Load frequency 
control of number of areas interconnected hydrothermal power reheat system. three areas interconnected consists of steam plant in three areas consists of hydro plant, the arrangement of most complex system like hydro plant and steam plant with reheat are interconnected that increases the nonlinearity of system. This model of technique is built in Simulink $\backslash$ MATLAB. The results show a conventional controller and intelligent with the addition of slider gain provide a good performance in each area of hydrothermal combination and reduce the oscillation of the frequency variation and the tie line power flow. A comparison of Artificial Intelligence with PI controller illustrates the excellence of proposed ANN based advance more Fuzzy and PI for the conditions. the intelligent control advance using ANN conception is supplementary perfect and more rapidly than the fuzzy and conventional PI controls diagram even for a difficult dynamical system[4]. In this study applied a Neural Network based PI and PID controllers design and simulated of a pneumatic servo actuator to increase the position accuracy. Pneumatic servo actuators in employment systems are usually used in industrial mechanization. In these designs training Neural Network depending on feedback representing change in location error and changes in external load force to present controllers with appropriate gain , these gains must be keep the positional response of overshoot, rise time and steady state error as minimum. The results show the Neural Network based PID controller was more than with PI controller in trained and generate with simpler construction and minimum Mean Square Error [5].

The aim of this research is to control of variables pressure and temperature of boiler of Al-Dura power plant in Baghdad which affected of maximum generated power and plant performance by intelligent technique and compared between them.

\section{Research Methodology}

\subsection{Artificial neural networks}

The first time of appear artificial neural network by Bernard Widrow in 1950's [6]. An artificial neural network is a computing structure that is made up of a assembly of simple, very much interconnected by neurons with transfer functions. The Neurons are including input layer, hidden layer and output layer. The system dynamic complexity is determined by the number of hidden layer and neurons in layers for ANN model. ANN learns by training .all inputs of ANN has its own weight. The Weights are determined during network training process. Neural network attempted to look like the human brain to resolve difficult problems in many applications in the field of engineering. Figure 1 shows a simple structure of a ANN with one input, one outputs and Figure 2 shows multipleinput neuron structures where $p, w, b, f$, and $a$ are input, weight, bias, transfer function, and output correspondingly. Formula 1 allows calculating the neuron output:

$$
a=f(w \cdot p+b) \text {. }
$$

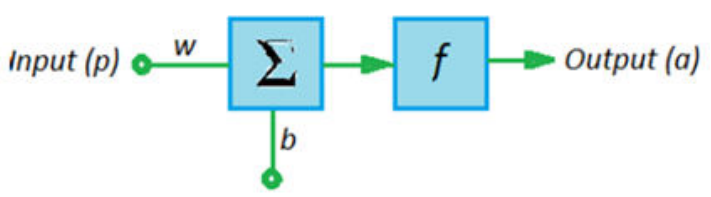

Figure 1 - Single-input neuron structure [7]

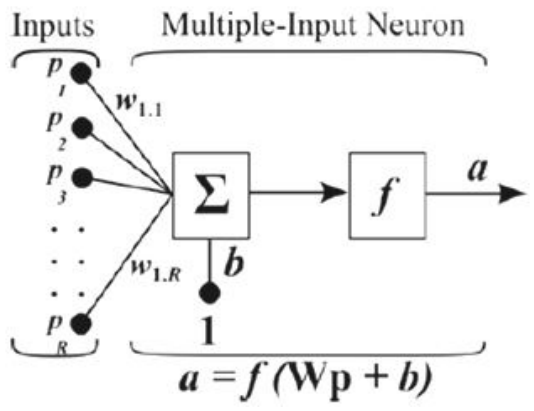

Figure 2 - Multiple-input neuron structure [7]

The variables $w$ and $b$ can be determined by learning rules so that the relation between the input and output meet the predictable aim [7].

Training of ANN can be classified in to types supervised and unsupervised. In supervised learning means that inputs and targets are known, but in unsupervised learning the inputs are known but unknown targets and the underlying relation within the data sets have to be disclose by the ANN utilized the data cluster method.

The training procedure of neural network involves the variation of parameters. So, it is needed to adjust the number of neurons in the hidden layer so as to reach the greatest converging network. A true process of training ANN is generally base on an iterative estimate in which the variables are in succession updated in numerous steps. Such a step can be based on a single information item, on a set of them, or on all obtainable data points. In each step, the desired outcome is compare with the real one and using the data of the architecture, all variables are changed slightly such that the error for the presented data points decreases [8]. Artificial neural networks (ANN) are useful in many fields of science, knowledge and technology. They provide an alternative approach to the simulation of complex, ill-defined and uncertain systems [9$11]$.

\subsection{PID control}

The widely utilized in industrial control systems is a proportional-integral-derivative (PID) controller due to their suppleness for give the designer on the system dynamics. it was introduced to industry in 1939. PID is a generic feedback control system that objective is to minimize the values of a measured and a desired difference by adjusting the process control inputs this called error. The PID controller consist of three coefficients the proportional $P$, the integral $I$ and the derivative $D$ values that can be translate in terms of time. The controller PID can present the requisite control action designed for a exact process by regulate present error, accumulation of past errors, and calculation of future errors [12]. It is also 
usual to use just PI, PD, P or I controllers. The formula 2 shows the algorithm of PID:

$$
u(t)=K_{p}\left[e(t)+\frac{1}{T_{i}} \int_{0}^{t} e(\tau) d \tau+T_{d} \frac{d e(t)}{d t}\right],
$$

where $u$ - control signal; $e$ - control error; $K_{p}-$ proportional gain; $T_{i}$ - integral time, and $T_{d}$ - derivative time.

The amount of three parameters including $P, I$ and $D$ acts control signal [13].

Figure 3 shows the block diagram of PID controller, where $y$ and $r$ are the measured process and reference parameters.

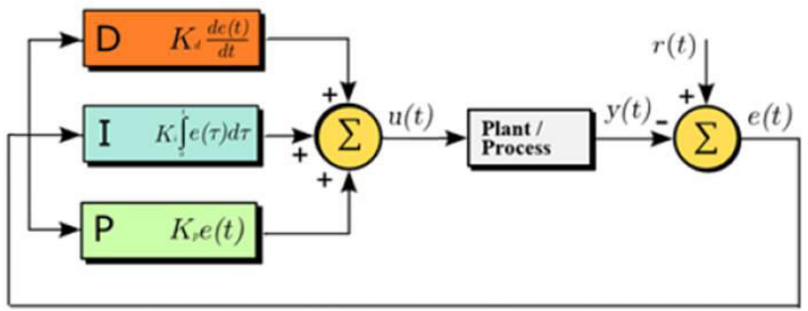

Figure 3 - Block diagram of PID controller [7]

\subsection{Modeling of boiler using PID and neural network}

The Simulink-MATLAB is used to design and implement an artificial neural network and PID controller. Adjust the gain of PID according to tuning algorithm in MATLAB to obtain a excellent balance between performance and robustness, and saving the system working in . The type of artificial neural network controller using is the nonlinear autoregressive moving average (NARMA) are designed and employed to control of pressure and temperature of boiler of steam power plant. NARMA implement in the ANN toolbox of simulation MATLAB. In system identification of ANN model of the plant is developed. Controller block of NARMA is shown in Figure 4.

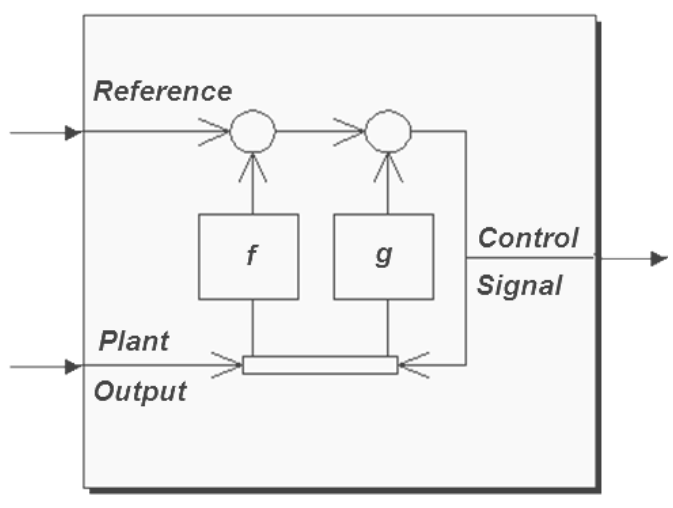

Figure 4 - Controller block of NARMA

The scheme of plant identification for the NARMA of boiler model is working by adjusted parameters for generating data by insert, min and max values for the plant input and output , min and max interval values. The size of the hidden layer, the number of delayed plant inputs and outputs, the sampling interval and finally the training function is the Levenberg-Marquardt Training Algorithm (TrainLM). The training network then select by the response of the resulting plant model was display. Separate plots for validation data, training data and testing data that's shown in Figures 5-7. The performance of neural net work and regression is shown in Figures 7, 8. The block controller of PID is shown in Figure 9, as well as the model of boiler using PID and Neural network is shown in Figure 10.

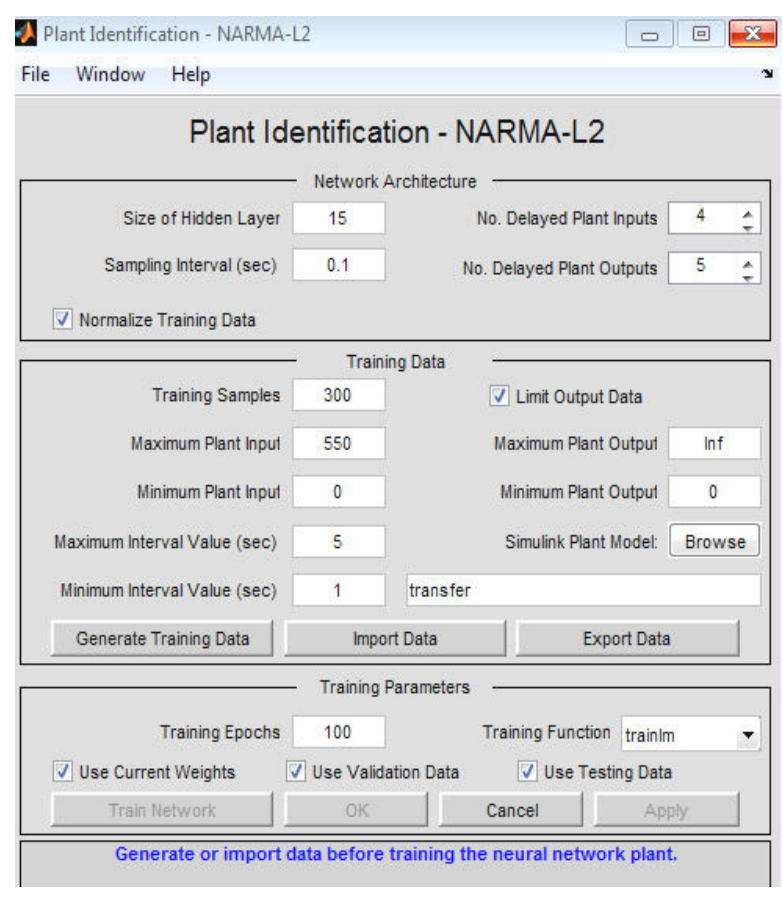

a

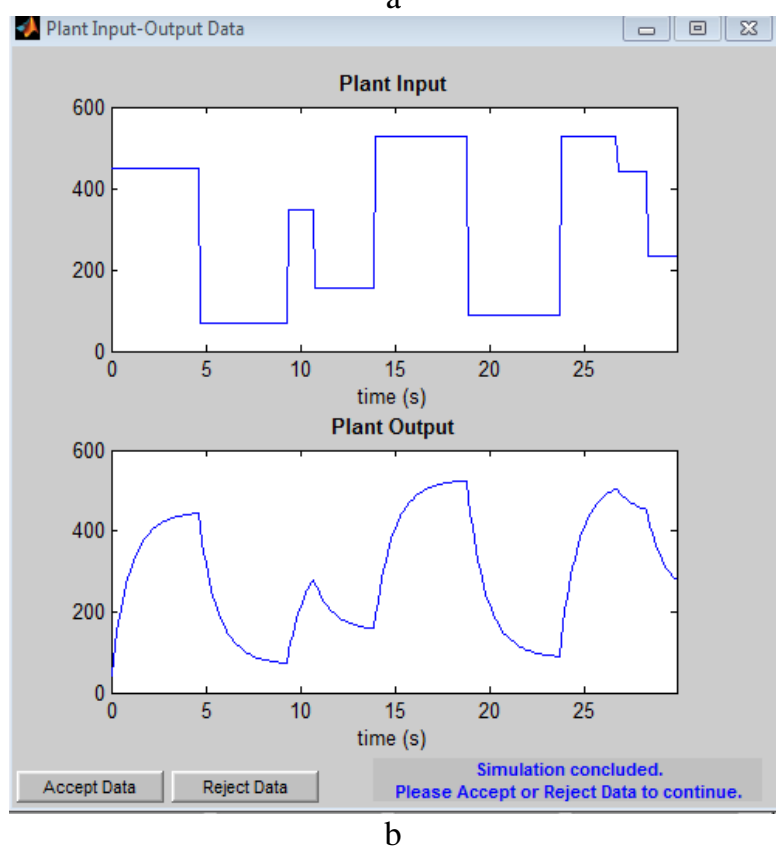

Figure 5 - Plant identification of NARMA (a) and generate data (b) 

\begin{tabular}{l} 
D Testing data for NN NARMA L2 \\
File Edit View Insert Tools Desktop Window Help \\
\hline
\end{tabular}
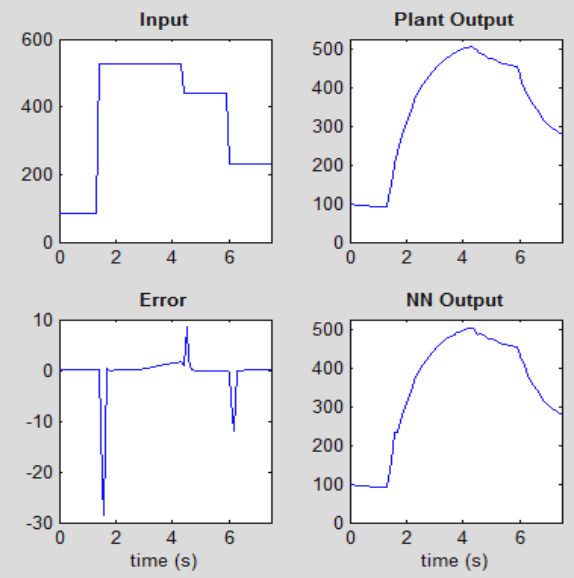

a
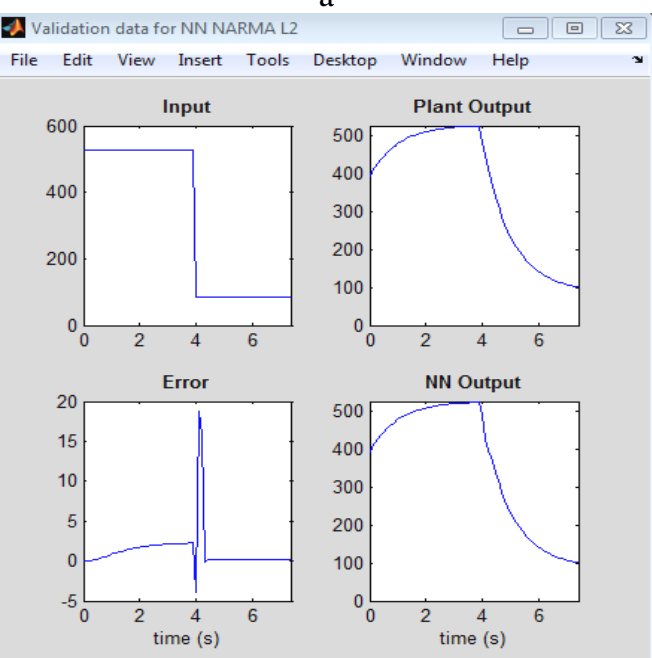

b

Figure 6 - Testing (a) and validation data (b) of neural network

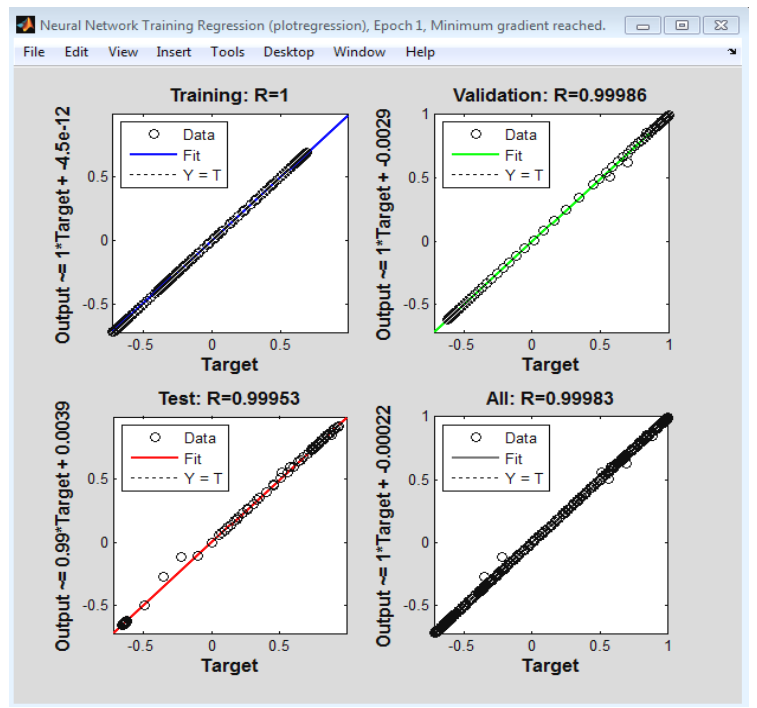

Figure 8 - Regression of neural network

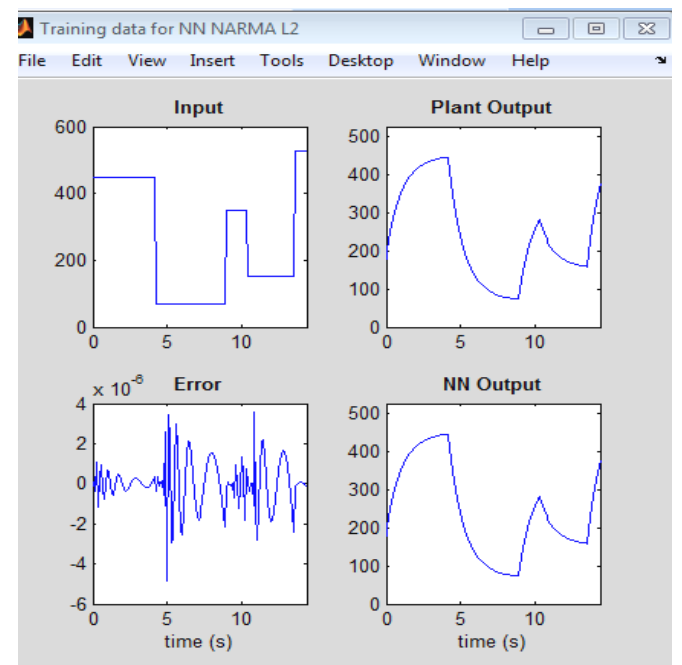

a

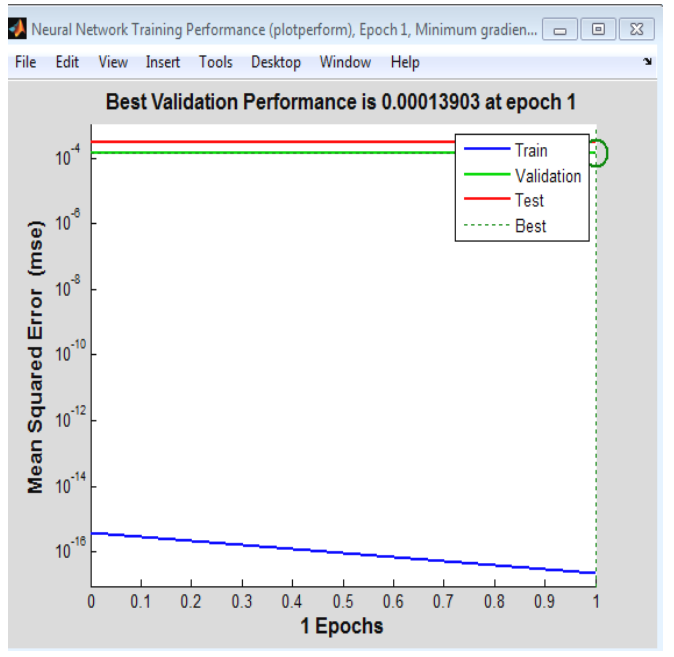

b

Figure 7 - Training data (a) and performance (b) of neural network

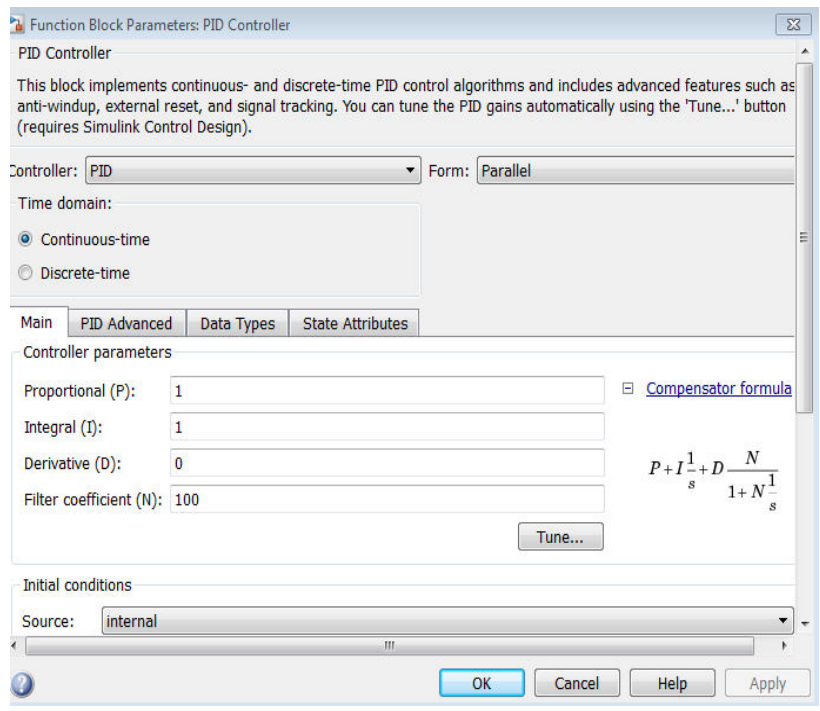

Figure 9 - Block controller of PID 


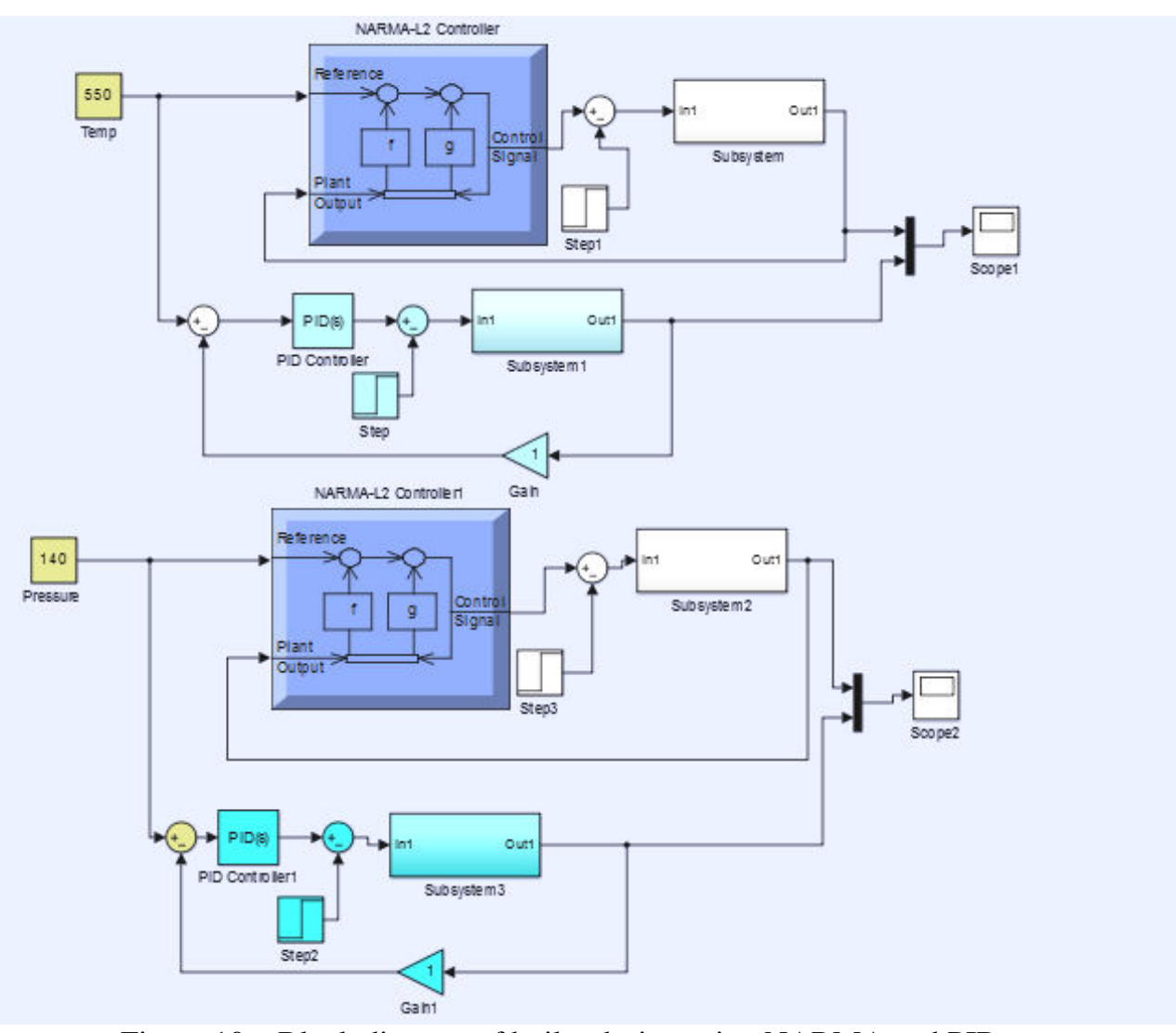

Figure 10 - Block diagram of boiler design using NARMA and PID

\section{Results and Discussion}

The combination of two or more of intelligent techniques produces a strong system of high efficiency and effectiveness. Intelligent techniques are very useful in the modeling and predicting of high complex systems having nonlinearity and uncertainty in their models. In some applications of more than one part in their systems, it is very difficult to evaluate or drive such mathematical models which can identify these systems, however, by obtaining some data for the inputs and outputs of system.

When implementation Simulink model of whole system, the results shown in Figure 11 allow obtaining the responses of pressure and temperature of model. As it can be see from these figures the response of the controller using neural network is rapid and after about 7 second it is stabilized but when using PID the response of the controller is stabilize after 18 second. From this result show the artificial neural network response is better than PID. These advantages are because of the special construction and algorithm of the network. Neural network method can be a suitable alternative to standard modelling techniques as obtain data sets show nonlinearities in the structure. It has established ability to solve combinatorial optimization troubles in engineering plants.

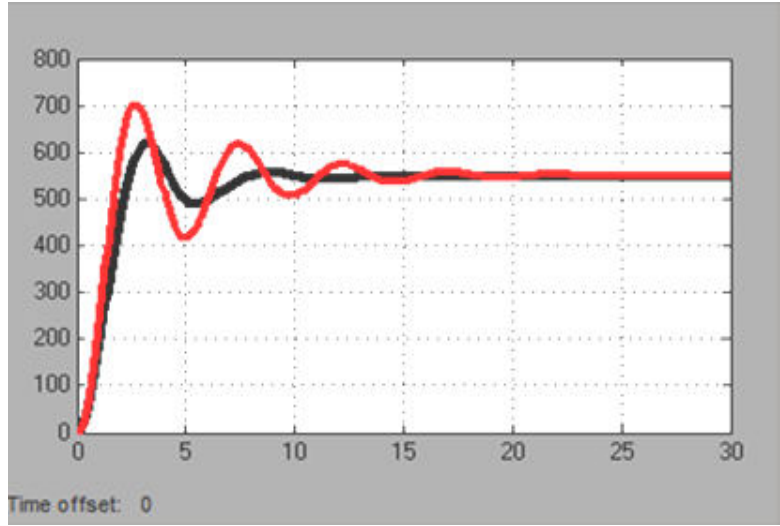

a

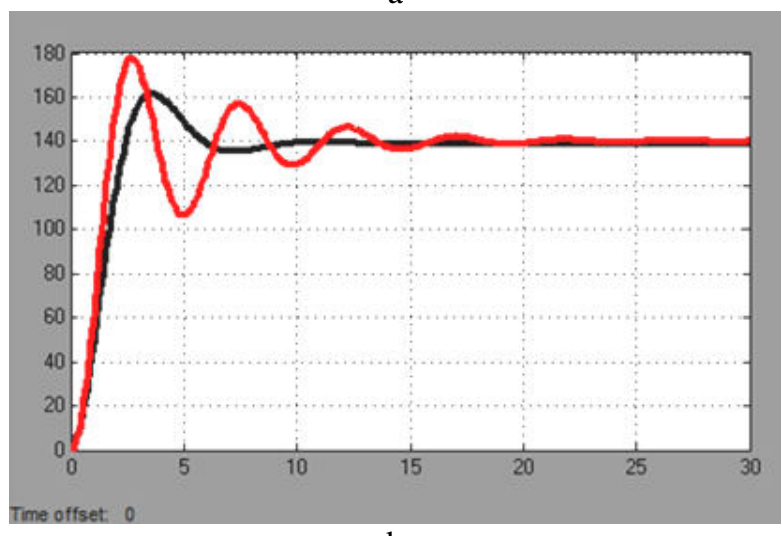

b

Figure 11 - The responses of temperature (a) and pressure (b) of a model 


\section{Conclusions}

This paper developed two types of controller structures for two significant outputs from the models and their matching values from the measured information sets temperature and pressure of boiler steam generation . These controllers of steam generation are NARMA of Artificial neural network controller and PID conventional controller. These controllers applied and adjusted their parameters and tune in Simulink $\backslash$ MATLAB according to the requirement of the steam generation structure and the control object. Finally compared and explored the performances of the Artificial neural network and PID conventional controllers .The result obtained that NARMA give a higher performance to PID controllers in this study. The response of rise, settling time, and maximum overshoot of NARMA is less than the for the PID controller. In general, the physical behaviour is well to hold by the NARMA models. It is also shown that neural networks are considered a reliable alternative to PID for identification and modelling systems.

\title{
References
}

1. Junghui, C., \& Tien-Chih, H. (2004). Applying Neural Networks to On-Line Updated PID Controllers for Nonlinear Process Control. Journal of Process Control, Vol. 14 (2), pp. 211-230.

2. Khalil, R. A. (2012). Comparison of Four Neural Network Learning Methods Based on Genetic Algorithm for Non-Linear Dynamic Systems Identification. Al-Rafidain Engineering, Vol. 20 (1).

3. Henriques, J., Gil, P., Cardoso, A., \& Dourado, A. (2002). Scheduling Of PID Controllers by Means of a Neural Network with Application to a Solar Power Plant. IEEE-IJCNN.

4. Prakash, S., \& Sinha, S. K. (2011). Load Frequency Control of Three Area Interconnected Hydro-Thermal Reheat Power System Using Artificial Intelligence and PI Controllers. International Journal of Engineering, Science and Technology, Vol. 4 (1), pp. 23-37.

5. Hassan, M. Y., \& Kothapalli, G. (2010). Comparison Between Neural Network Based PI And PID Controllers. International Multi-Conference on Systems, Signals and Devices, pp. 1-6.

6. Asgari, H., Chen, X. Q., \& Sainudiin, R. (2012). Application of Artificial Neural Networks to Rotating Equipment. 3rd Conference on Rotating Equipment in Oil and Power Industries.

7. Hagan, M. T., Demuth, H. B., \& Jesus, O. D. (2002). An Introduction to the Use of Neural Networks in Control Systems. International Journal of Robust and Nonlinear Control, Vol. 12 (11), pp. 959-985.

8. Beale, M. H., Hagan, M. T., \& Demuth, H. B. (2011). Neural Network Toolbox ${ }^{\mathrm{TM}}$ User's Guide. Mathworks.

9. Pallares, D., Johnsson, F. (2006). Macroscopic modelling of fluid dynamics in large-scale circulating fluidized beds. Progress in Energy and Combustion Science, Vol. 32 (5), pp. 539-569.

10. Zhao, C., Dun, L., Zhou, W., Chen, X., Zeng, D., Flynn, T., \& Kraft, D. (2012). Coal combustion characteristics on an OXYCFB combustor with warm flue gas recycle. Proceedings of the 21st International Conference on Fluidized Bed Combustion, pp. 3-6.

11. Kesgin, U. (2004). Genetic algorithm and artificial neural network for engine optimisation of efficiency and $\mathrm{NO}_{\mathrm{x}}$ emission, Fuel, Vol. 83 (7), pp. 885-895.

12. Araki, M. (1984). PID Control. Control, Systems, Robotics, and Automation, Vol. 2.

13. Astrom, K. J. (2002). PID Control. Control System Design, pp. 216-251.

\section{Порівняльний аналіз застосування пропорційно-інтегрально-диференціального регулятора і штучної нейронної мережі для керування паровим котлом електростанції}

\author{
Салім Х., Султан Х. Ф., Джавад Р.
}

Технологічний університет, вул. аль-Сінаа., 10066, м. Багдад, Ірак

\begin{abstract}
Анотація. У статті представлено розроблену методику проведення порівняльного аналізу застосування нейронних мереж і контролерів для традиційних котлів парових електростанцій. Представлені схеми двох різних контролерів для тиску і температури для підтримки роботи котла в нормальному стані та підвищення ефективності. Ці контролери складаються з нелінійного NARMA-контролера штучної нейронної мережі та традиційного пропорційно-інтегрально-диференціального регулятора. Ці параметри коригуються шляхом побудови моделі та подальшої реалізації у програмі MATLAB відповідно до вимог парової електростанції та цілей управління. Результати свідчать, що нейронна мережа контролюється краще, а на електростанції Аль-Дюра у м. Багдад застосовуються характеристики відповідної моделі електростанції з використанням PID-контролера i штучної нейронної мережі, що може бути черговим підтвердження ефективності застосування нейронних мереж у багатьох галузях промисловості.
\end{abstract}

Ключові слова: штучна нейронна мережа, керування, PID-контролер, NARMA. 